\title{
On The Beta-Glucuronidase Binding Protein (BGBP) Of Microorganisms.
}

\author{
Its Purification, The Antiserum Preparation Against That \\ And Its Localization In Leproma And The Other Infectious \\ Lesions Shown By Immunohistologic Method.
}

\author{
Eiichi Matsuo ${ }^{1)}$, Akio Komatsu ${ }^{1)}$, Suguru Maekawa ${ }^{1)}$, Yukihiro Furuno ${ }^{1)}$, \\ Akiko Matsushita ${ }^{1)}$, Ayumi Sumiishi ${ }^{1)}$, Norisuke Sasaki ${ }^{2)}$ \& Olaf K. Skinsnes ${ }^{3)}$, \\ Department of Pathology, 1) Kyorin University School of Medicine, \\ 2) Tohoku Shinseien \& 3) Sun Yat-Sen University of Medical Sciences \\ (Received for publication: August 31, 1993)
}

Key Words: Leprosy, $\beta$-glucuronidase, $\beta$-glucuronidase binding protein.

\section{SUMMARY}

Our previous studies suggested that $M$. leprae (ML) grow in peripheral nerves and lepra cells because ML metabolize hyaluronic acid (HA), and use its component for their growth by the aid of host enzyme combined to the bacilli derived $\beta$-glucuronidase binding protein (BGBP). In this study, therefore, we examined the method to purify BGBP from a mycobacterium $H I-75$ originally separated from a leproma and cultured by modified Ogawa's medium containing split products of $\mathrm{HA}$ (glucuronic acid and $\mathrm{N}$-acetylglucosamine). The distribution of $\mathrm{BGBP}$ in leproma and the other lesions consisting of hepatitis B virus infected liver and $M$. avium-intracellulare infected lung tissue were also immunohistologically examined.

As the result, the best method to get $\mathrm{BGBP}$ was preparatory electrophoresis in the final step of the purification and not the molecular sieving. The BGBP was actually proven in leproma and the other infected tissues as described, indicating the abilities of these microorganisms to utilize the metabolic machinery of the host with the similar ways to that of ML.

\section{INTRODUCTION}

The understanding of the metabolism of $M$. leprae (ML) to make the parasitism of ML in peripheral nerves and lepra cells of patients is one of the most interesting subject in leprology. We have assumed that ML have the affinity with and metabolize hyaluronic acid (HA), based on the results of histochemical studies on the above sites of parasitism showing the abundance of $\mathrm{HA}$ and its degrading enzyme encompassing $\mathrm{ML}^{1}$. Therefore, we tried to extract $\beta$-glucuronidase (B-Gase), though unsuccessfully ${ }^{2}$, from a mycobacterium HI-75 (HI-75) which was isolated from a leproma, claimed as ML by Skinsnes et $\mathrm{al}^{3}$. and has been kept on cultivating thereafter. The reason of the choice of HI-75 for that purpose is, the intraneural invasion and growth of the bacilli in the inoculated mice as one of its characteristics, though the reports by Stanford et $\mathrm{al}^{4}$ and Fujimiya et $\mathrm{al}^{5}$ concerning about the matter are quite controversial. The latter investigators reported that they observed the nerve invasion of HI-75 in the infected mice. However, besides Stanford et al., Tasaka identified HI-75 as $M$. scrofulaceum (MS) based on the observation of an immunoprecipitation line between his spe- 
cific antiserum ${ }^{6}$ to alpha antigen of MS and the extract of HI-75 by the gel diffusion method. Genomic study consisting of ML-specific polymerase chain reaction amplification assay (PCR) and restriction fragment length polymorphism (RFLP) analysis by Williams, LL $^{7}$ in 1991 revealed that HI-75 looks neither like ML nor MS. It rather resembled to either $M$. fortuitum or $M$. smegmatis according to her. Therefore, we have to evaluate highly the results on HI-75 by the current identification methods for $\mathrm{ML}$ especially of the genomic ones. We have to clarify the reason of these discrepancies in future by ourselves. In the mean time the ability of $\mathrm{HI}-75$ to grow in nerves according to $\mathrm{Fu}$ jimiya et al, provides us a basis to utilize the bacilli as the source to extract B-Gase ${ }^{2}$, previously and the binding protein for the enzyme this time. The reason to take Fujimiya's report seriously is that the nerve involvement has been regarded as a characteristic of leprosy ${ }^{8,9}$, and therefore, of ML. No other mycobacterium is known to show the intraneural growth of the bacilli so far. However, the HI-75 do not seem to have at least the extractable amount of B-Gase, in spite of our effort to get B-Gase in the past ${ }^{2}$. Instead, we have observed human B-Gase in leproma which was immunohistologically stained utilizing anti-human BGase $^{10}$.

In this study, we tried to get the evidence that ML in leprosy patient obtain B-Gase activity by fixing the host enzyme to the bacilli-derived B-Gase binding protein (BGBP), by immunohistologically confirming its presence in leproma. To do so, we also selected the best method to extract BGBP from HI-75.

\section{MATERIALS AND METHODS}

Culture of a mycobacterium HI-75: Modified Ogawa egg media were prepared by either of the following two methods. In the first one ${ }^{11}$, we added $1 \mathrm{ml}$ of autoclaved physiological saline containing $1 \%$ each of both glucuronic acid (GA) and $\mathrm{N}$-acetylglucosamine (NAG) to each prepared Ogawa egg medium (Eiken Chemical Company), containing $7 \mathrm{ml}$ of $3 \%$ medium in each tube, immediately after the bacilli were inoculated to the media. In the second $\operatorname{method}^{12,13}$, for the recovery of the large amount of bacillary pellet, we put $100 \mathrm{ml}$ each of basal solution of egg medium containing 1\% each of GA and NAG into Wheeton's liquid medicine bottles with the capacity of $400 \mathrm{ml}$ and inspissated at $95^{\circ} \mathrm{C}$ for 60 minutes or autoclaved at $121^{\circ} \mathrm{C}$ for 15 minutes to make slopes in the bottles. The bacilli showed full growth after the cultivation for three to four months at $37^{\circ} \mathrm{C}$. The tubes and bottles containing medium and bacilli were autoclaved before the separation of the bacilli. The colonies of the HI-75 were washed off by vigorous pipetting with phosphate buffered saline, pH 7.4 (PBS) and the suspension of the bacilli were mixed to make the final ethanol concentration of $68 \%(\mathrm{v} / \mathrm{v})$ and all precipitates including the bacilli, were recovered by centrifugation at $7,000 \mathrm{G}$ for 30 minutes and dehydrated with acetone (Fr. 1).

B-Gase activity of HI-75: The B-Gase activity of the viable bacilli, directly scraped off the culture bottles was tested in comparison with that of $E$. coli (rehydrated lyophilized product by Sigma) utilizing SwabzymeTM -Betaglucuronidase, $(\mathrm{E} \cdot \mathrm{Y}$ laboratories, INC.).

Purification of BGBP from HI-75 ${ }^{14,15}$ : Fr. 1, was suspended five times with $\mathrm{PBS}$, containing $1 \mathrm{mM}$ of EDTA, and mixed by the ratio with $1 \mathrm{mg}$ of Difco's trypsin/250mg of Fr. 1 (dry weight). The suspension was kept at $37^{\circ} \mathrm{C}$ for 3 hours adjusting its $\mathrm{pH}$. around 7.4 to 8.0. After the digestion the suspension was vigorously mixed with equal volume of chloroform up to 15 minutes using blender and centrifuged at $7000 \mathrm{G}$. Ethanol was mixed to the recovered supernatant to make the final concentration of $68 \%(\mathrm{v} / \mathrm{v})$ and the mixture was kept overnight 
in a refrigerator. The resulted precipitate was collected by centrifugations and dehydrated with acetone (Fr. 2). Preparatory electrophoresis (with the Furicoverer, Fuji Riken) of the Fr. 2 were performed monitoring the absorbance (O.D.) of eluted fractions at $280 \mathrm{~nm}$. In the procedure, carrier was Gel Mix 6 (Life Technologies, Inc.), containing $6 \%(\mathrm{w} / \mathrm{v})$ acrylamide/bisacrylamide monomers, $100 \mathrm{mM}$ Tris-borate $(\mathrm{pH}$ 8.3), $1 \mathrm{mM} \mathrm{Na} \mathrm{Na}_{2}$ EDTA, and $7 \mathrm{M}$ urea, which was solidified with $10 \%(\mathrm{w} / \mathrm{v})$ ammonium persulfate in two glass columns, $2 \mathrm{~cm}$ in diameters and $8 \mathrm{~cm}$ in lengths. The lengths of two gels, separation and stopper ones, were $4 \mathrm{~cm}$, each. Charged amount of Fr.2 was $140 \mathrm{mg} / \mathrm{ml}$, each time. Electrophoresis was performed at $27 \mathrm{~mA}$. Total void volume was $162 \mathrm{ml}$ in 21 hours at the flow rate of $0.13 \mathrm{ml} / \mathrm{min}$.

High performance liquid chromatography ${ }^{16}$ (HPLC) of BGBP ${ }^{17}$ : It was performed utilizing a column of octadecylsilica, $46 \mathrm{~mm} \times 150 \mathrm{~mm}$ (Inertsil ODS 5, GL Sciences Inc. Tokyo) for the elution by a 0 to $100 \%$, linear isopropanol concentration gradient in $\mathrm{H}_{2} \mathrm{O}$ containing $0.1 \%$ trifluoroacetate. Sample applied was $50 \mu 1$ of 0 . $1 \% \mathrm{BGBP}$ and its flow rate was $1 \mathrm{ml} / \mathrm{min}$. The absorbance of eluted fraction was monitored at 230nm. Apparatus utilized was Beckman System Gold consisted of the programmable solvent module 126, programmable detector module 166 and the personal chromatograph.

Molecular sievings of the BGBP of $\mathrm{HI}-75^{17}$ : The first one of the two procedures was performed to get an elution curve of $10 \mathrm{mg}$ of BGBP with 5mg each of albumin (M.W.: 67,000) and chymotrypsinogen A (M.W.: 25,000) as markers (Pharmacia Fine Chemicals) which was performed using a column, sized $1 \mathrm{~cm}$ in diameter and $55 \mathrm{cms}$ in the height of gel, packed with Sephacryl S-200, high resolution (Pharmacia). Elution was performed using $0.05 \mathrm{M}$ phosphate buffer, $\mathrm{pH} 8.0$, containing $0.1 \mathrm{M} \mathrm{NaCl}$ (cf. Fig. 3). The similar sieving of $10 \mathrm{mg}$ of BGBP was also performed using $5 \mathrm{mg}$ each of ovalbumin (M.W. 43,000) and ribonuclease A (M.W.: 13,700) as markers (cf. Fig. 4). Flow rates were $14.5 \mathrm{ml} /$ hour in both procedures.

Activity of BGBP $^{14}$ : The BGBP solution was $0.164 \%$ by protein concentration which was estimated by micro TP-Test Wako kit (Wako Pure Chemicals). The solvent was PBS containing $1 \mathrm{mM}$ each of $\mathrm{CaCl}_{2}$ and $\mathrm{MgCl}_{2}$ (CMPBS). Each of these specimens, $0.025 \mathrm{ml}$ per a well, was placed for 30 minutes in the apparatuses for enzyme-linked immunosorbent assays (ELISA). Then the wells were washed several times with CMPBS. Specimens treated in the boiling water up to 5 minutes after dissolving with either CMPBS containing $6 \mathrm{M}$ urea or Laemmli's solution which contains sodium dodecyl sulfate (SDS) were also tested for the combination. After the blocking with $0.025 \mathrm{ml}$ of $3 \%$ bovine serum albumin (BSA), $0.025 \mathrm{ml}$ of CMPBS containing $16.7 \mathrm{mg}$ (833.3 units) of $\mathrm{B}$ Gase ( $\beta$-D-glucanohydrolase; EC 3.2.1.31) was placed in each well. The B-Gase utilized was purified one from bovine liver, type B-1 (Sigma). After the washing of nitrocellulose sheet with CMPBS the activity of bound BGase was examined utilizing Naphthol AS-BI glucuronide as substrate prepared according to the method of Hayashi et $\mathrm{al}^{18}$.

Anti-BGBP-antiserum: Three male rabbits weighing about $2 \mathrm{~kg}$, each at the start of the immunization were injected with the BGBP, suspended with physiological saline and homogenized with incomplete adjuvant, initially into foot pads then into muscles of buttocks, $1.2,2.2 \mathrm{mg}$, respectively at the beginning and 9 weeks thereafter. Then each rabbit was intravenously injected with $1 \mathrm{ml}$ of saline each time containing $8.5 \mathrm{mg}$ once and $10 \mathrm{mg}$ twice of BGBP at 15,28 and 29 weeks after the start of immunization. The rabbits were exsanguinated a week after the last immunization. Two rabbits out of three survived until the 
exsanguination. The sera were inactivated at $56^{\circ} \mathrm{C}$ for 30 minutes, pooled together and $50 \mathrm{ml}$ of them were fractionated by mixing with $7 \mathrm{~g}$ of sodium sulfate. The precipitate was centrifuged down at $10,000 \mathrm{G}$. and was reconstituted with $10 \mathrm{ml}$ of PBS and diluted $500 \mathrm{X}$ with PBS when used for immunohistologic stain.

Immunoassays of the anti-BGBP antiserum: Those were performed using ELISA $^{19}$ utilizing multi-wells plastic plates and the apparatus for dot ELISA and passive hemagglutination ${ }^{20}$. In the ELISA assays, BGBP was combined with $\mathrm{BSA}$ at the ratio of one to one by weight, according to the method of Avrameas ${ }^{20}$, and suspended to make the $0.05 \%$ solution. The antigen solution was placed in the wells for 30 to 40 minutes at room temperature in both procedures. Blockings were made with $10 \%$ normal goat serum in ELISA and with 1\% BSA in dot ELISA. Washing and dilution throughout the study was made using $10 \mathrm{mM}$ phosphate buffered saline, pH 7.2 in ELISA and $0.1 \%$ Tween 20 containing PBS in dot ELISA. For antigen antiserum reaction, the plates were left in a refrigerator, overnight or 20 minutes at $37^{\circ}$ C. The combined antiserum was developed using biotinilated anti-rabbit-IgG goat antibody, streptoavidine peroxidase, followed by the solution containing $0.05 \%$ each of 0 phenylenediamine and $\mathrm{H}_{2} \mathrm{O}_{2}, 5$ minutes in case of ELISA and $0.025 \%$ 4-chloro-1-naphthol and 0 . $05 \% \mathrm{H}_{2} \mathrm{O}_{2}$ for up to 15 minutes in case of dot ELISA. The reaction was, then, suppressed by $1 \mathrm{~N}-\mathrm{HCl}$ and was estimated by the absorbances at 405 and $450 \mathrm{~nm}$ in ELISA. In passive hemag. glutination test $(\mathrm{PHT})^{21}, 0.5 \% \mathrm{BGBP}$ was combined to glutaraldehyde fixed and tanned sheep red blood cells (TSRBC). TSRBC suspension $(2 \%)$ was introduced into wells already containing antiserum serially diluted with PBS and left for 2 hours before the assay.

Immunohistologic staining for $\mathrm{BGBP}^{28}: \quad 10 \%$ formalin fixed and paraffin embedded tissue sections were studied. Those were skin with lepromatous leprosy, liver with hepatitis $B$, and lung with $M$. avium-intracellulare infection. The causative organisms of those diseases were confirmed by Nyka and O'Neill's modification of acid-fast stain ${ }^{24}$ for the mycobacteriosis and modified Orcein method for hepatitis B surface antigen ${ }^{23}$ prior to the immunohistologic staining. After thin sectioning, the tissue sections were deparaffinized with chloroform and then ethanol before the rehydration. Then, the sections were digested with small amount of hyaluronidase solution from Streptomyces hyalurolyticus containing 100 TRU per an ampoule (Seikagaku Kogyo), for two hours mounted to cover the sections at room temperature. After washing with PBS and blocking with PBS containing 1\% BSA, the sections were served for immunohistologic stain with avidine biotin complex method ${ }^{25}$. Controls consisted of the sites of same tissues without the bacilli apart from the site with the bacilli. In case of hepatitis $B$ viruus infected liver, the sites of coexisted hepatocellular carcinoma which was not stained with Orcein method served as the control.

\section{RESULTS}

Cultivation of HI-75: The bacilli grew well forming many confluent orange-yellow colonies in the surface of media, which could be easily washed off by splashing PBS by Komagome pipette. The recovery of the Fr. 1 from 353 tubes by the first method was $62.8 \mathrm{~g}$. The recovery by the second method was not much different from that by the first one. The yield of Fr. 2 from $62.8 \mathrm{~g}$ of Fr. 1 was $18.6 \mathrm{~g}$ by dry weight (29.6\%).

Activity of B-Gase of HI-75: The pellets of the viable bacilli did not show the activity of B-Gase with the SwabzymeTM $\beta$ glucuronidase unlike $E$. coli which showed deep red color of cotton swabs. 
Separation of BGBP from $\mathrm{HI}-75$ and its activity: As shown in the Fig. 1, BGBP was separated very well by means of preparatory electrophoresis. The BGBP appeared in the last fraction eluted, which was separated very discretely from the other fraction. The recovery of BGBP from $140 \mathrm{mg}$ of Fr. 2 was $34 \mathrm{mg}$ (24.3\%). The fraction seemed to be very well purified according to the elution curve by HPLC as shown in the Fig. 2. Molecular sievings of BGBP of HI-75 with marker proteins did not separate the BGBP well as shown in the Figs. 3 and 4 . There were atypical absorbances in the foot of the peaks of markers and absence of the solitary peaks of BGBP in both experiments.

Activity of BGBP: The activity of BGBP could be visualized by the method as written in the "materials and methods". The previous treatment of BGBP by SDS nullified its activity as shown by the Fig. 5 .

Anti-BGBP-antiserum: The titers of antiBGBP was $179200 \mathrm{X}$ by passive haemagglutina tion, $32000 \mathrm{X}$ by dot ELISA and $12800 \mathrm{X}$ with ordinal ELISA using multi-wells plastic plates.

Immunohistologic staining for B-Gase and BGBP: Anti-BGBP antiserum stained not only leproma (cf. Fig. 6) but M. avium-intracellulare (MAI) (cf. Fig. 7). In leproma, globi were also stained well like the other lepra cells containing ML. However, some of the immunoreactive sites seemed to be easily dispersed without the careful handling of the stained sections. In the cytoplasms of macrophages which were full with MAI the immunoreactive sites for BGBP were arranged discretely as though stained for the MAI themselves. In the hepatitis B virus infected liver, immunohistologically stained sections showed the similar localizations of BGBP in the liver cell cytoplasms (cf. Fig. 8) to those of hepatitis B surface antigen with modified Orcein method (cf. Fig. 9). The tissue section of hepatoma were stained neither by the immunohistologic stain for BGBP (Fig. 10) nor by the modified Orcein method (Fig. 11).

\section{DISCUSSION}

\section{Culture of HI-75 and its activity of B-Gase:} Our basis of the choice of HI-75 to extract BGBP was the ability of the bacilli to grow in the peripheral nerve of nude mice as was briefly reported by Fujimiya et $1^{5}$. Therefore, we have taken the nerve invasion of HI-75 most seriously over the other characteristics. However, it does not mean that we have neglected the other reports. In fact, we admit that it would be fascinating research subjects in future to study whether other microorganisms besides ML grow in nerves like HI-75 and its difference from ML by PCR and RFLP after the recovery from host animals besides that harvested directly from culture bottles. Meanwhile, though there might be some risk of misinterpretation of our past results without all of the answers to the above questions, the nerve invasion of HI-75, absence of B-Gase in HI-75 as shown previously ${ }^{2}$ and this time again and the presence of BGBP, cross-immunoreactive with that of $\mathrm{ML}^{15}$ as described below, facilitated us to draw the temporal conclusion that ML combine host B-Gase to its BGBP to use metabolic machinery of patients. The accelerated growth of HI-75 on culture, by GA and $\mathrm{NAG}^{11}$, split product of HA, than by HA itself, also support the speculation. It might be also interesting to cultivate and examine the nature of microorganisms directly derived from lepromata by either of two methods of proposed media preparation.

Purification of BGBP from HI-75: Concerning about the nature of this BGBP from HI-75, the present study, as was the previous on $e^{15}$, clearly indicated the weak negative charge at $\mathrm{pH} 8.3$ and a good separability by that condition by preparatory electrophoresis probably due to the presence of urea and EDTA. The fraction seemed to be very well purified according to the 


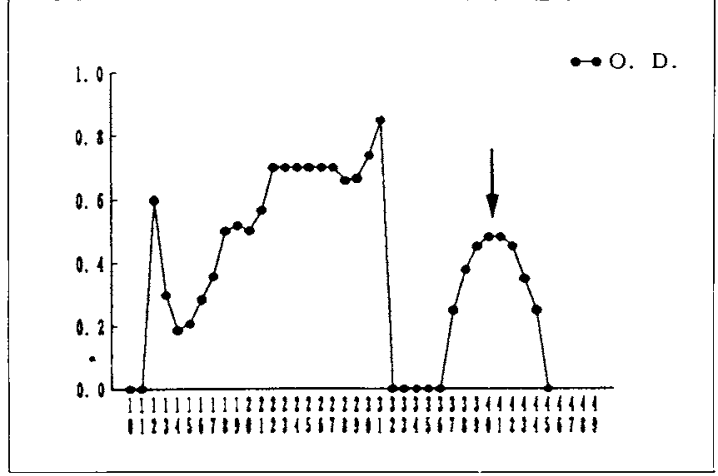

Fig. 1: An elution pattern of BGBP (arrow) by preparatory electrophoresis monitored by the absorbance at $280 \mathrm{~nm}$ showing a distinct peak, well separated from the others.

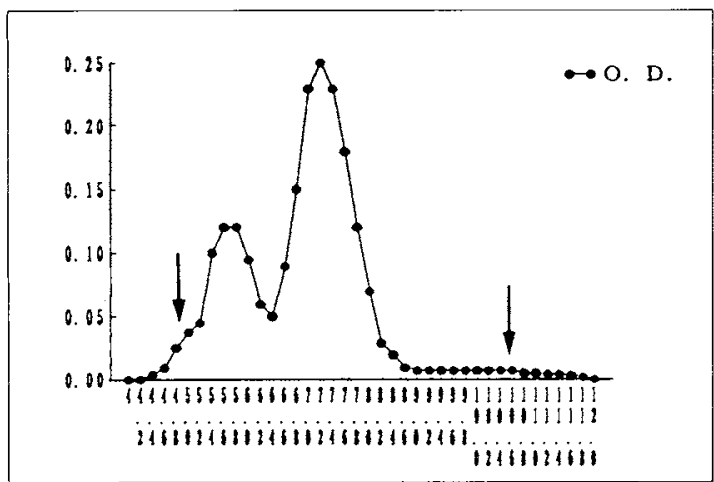

Fig. 3: An elution pattern on molecular sieving of BGBP with albumin and chymotrypsinogen A. Note the presence of atypical absorbance (arrows) in the foot of the peaks of markers and the absence of the peak of BGBP itself.

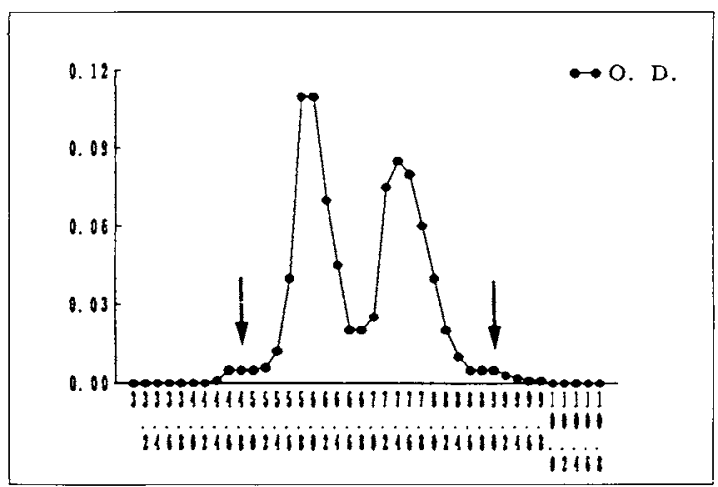

Fig. 4: An elution pattern on molecular sieving of BGBP with ovalbumin and ribonuclease A as markers. Note the presence of atypical absorbance (arrows) in the foot of the peaks of markers and the absence of the peak of BGBP itself.

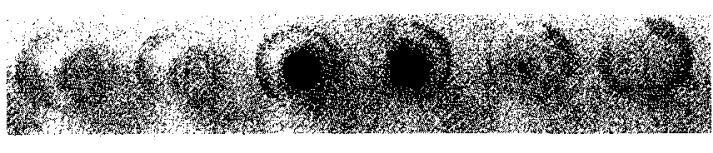
1
2
3
4
5
6

Fig. 5: The sites of the activity of B-Gase, combined to BGBP which were bound to nitrocellulose sheet were stained with the method according to Hayashi et al. The dots 1 and 2 which combined BGBP, treated with SDS instead of original BGBP did not show the enzyme activity. The dotts 3 and 4 which combined BGBP showed the enzyme activity. The dotts 5 and 6 which were placed with CMPBS alone without BGBP did not show the enzyme activity.

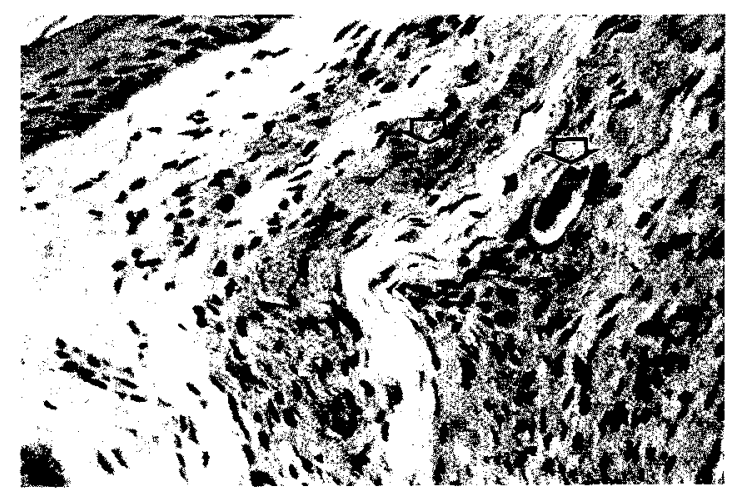

Fig. 6: A leproma, immunohistologically stained for BGBP, counterstained with hematoxylin. Gray tone of lepra cells and globi (arrows) indicates the sites of the immunoreactivity, and therefore, the localization of the BGBP.

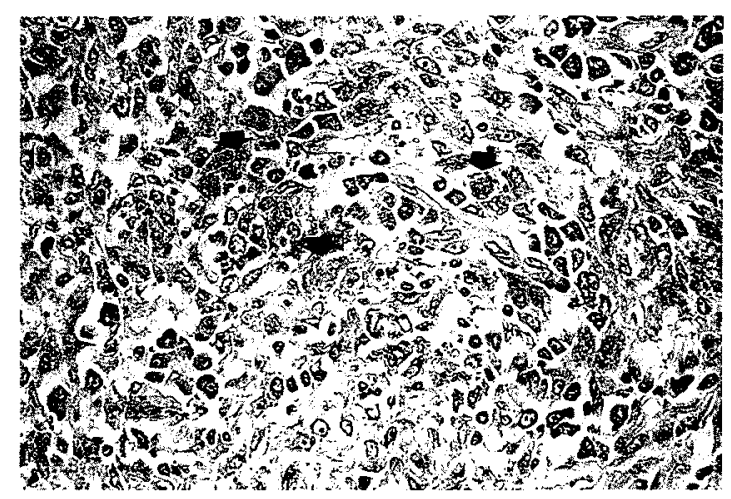

Fig. 7: An inflammatory lesion, immunohistologically stained for BGBP and counterstained for nuclei with hematoxylin, showing the histiocytic infiltration associated with the infection of $M$. avium-intracellulare. The gray tone of the cytoplasms of histiocytes indicate the immunoreactivity for BGBP and the presence of the bacilli (arrows). 


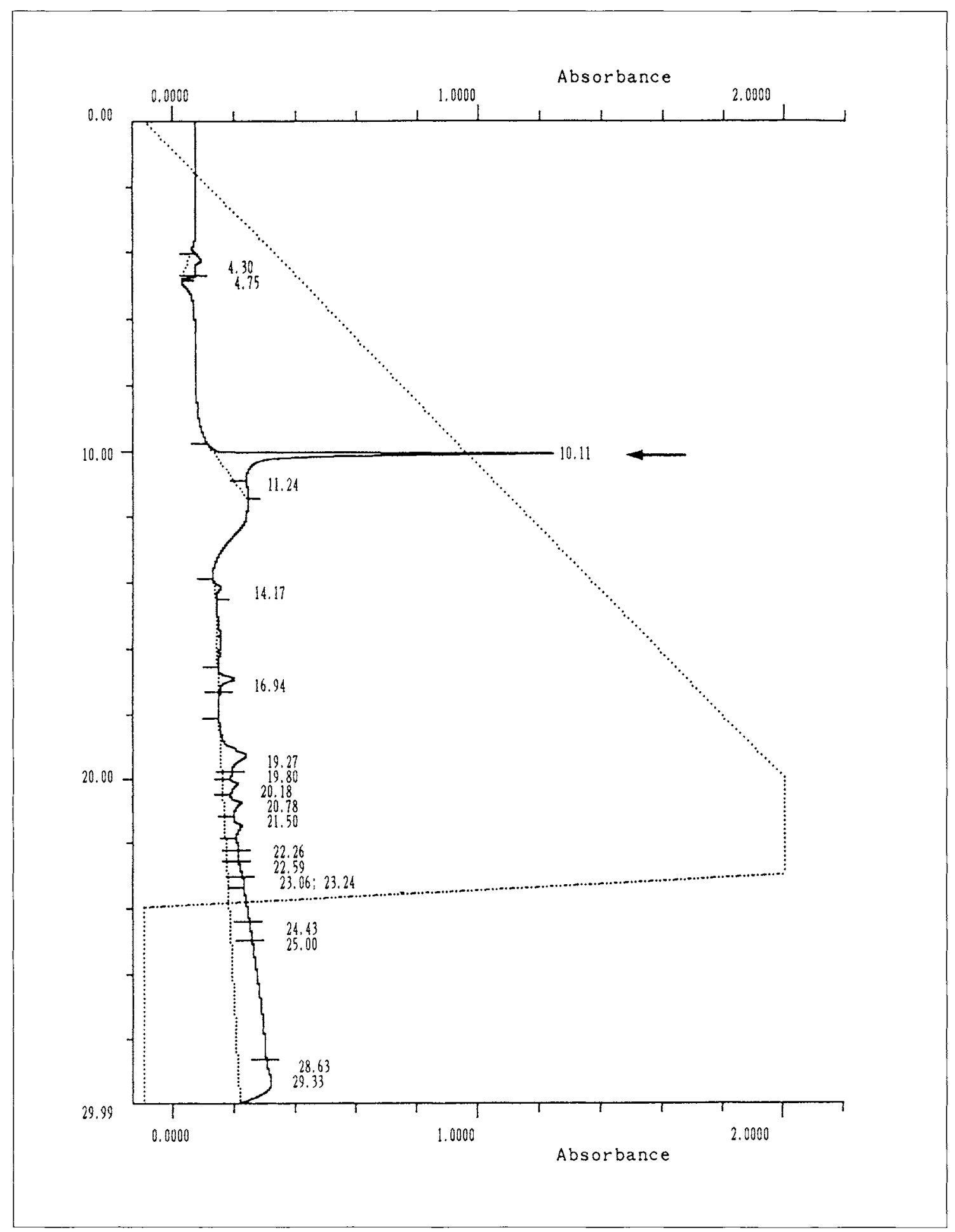

Fig. 2: An elution curve of BGBP (arrow) by HPLC showing some tailing but the good purity. 


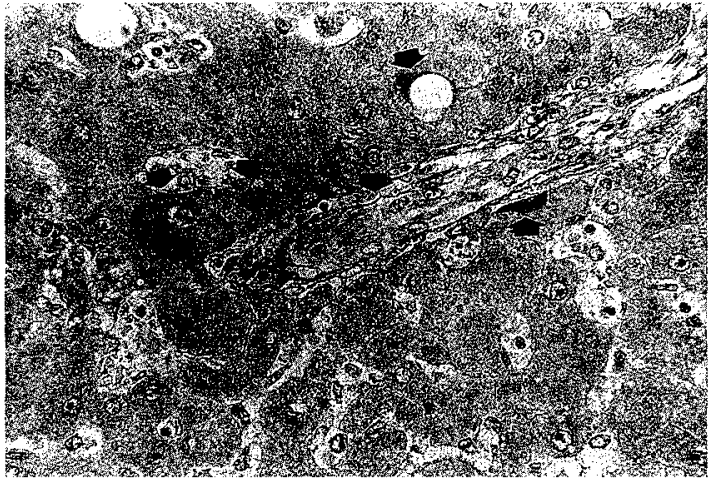

Fig. 8: The photomicrograph of liver in the same case as that of Fig. 9 immunohistologically stained for BGBP. The immunoreactive sites (arrows) are located in the cytoplasms of some liver cells and therefore showing the similar staining pattern as that of Orcein stain except the connective tissue (arrow $\mathrm{C}$ ) of portal triad was not stained by this method.

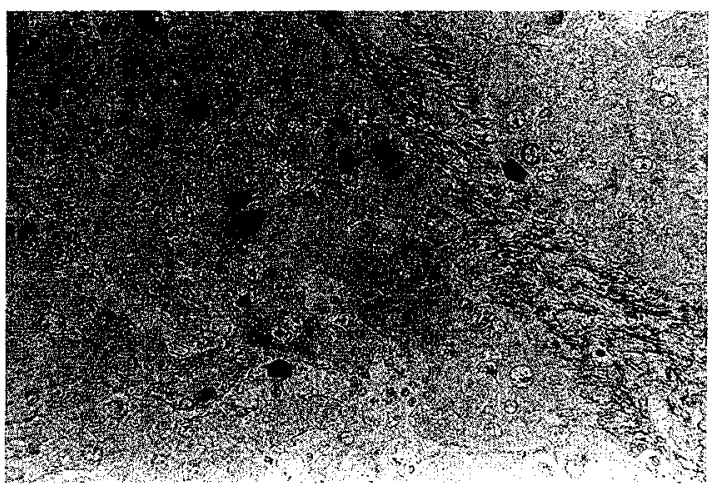

Fig. 9: The photomicrograph of liver section stained with modified Orcein method for hepatitis B surface antigen. The positive stain (arrows) located in the cytoplasms of some liver cells. The connective tissue (arrow C) of portal triad was also stained by this method.

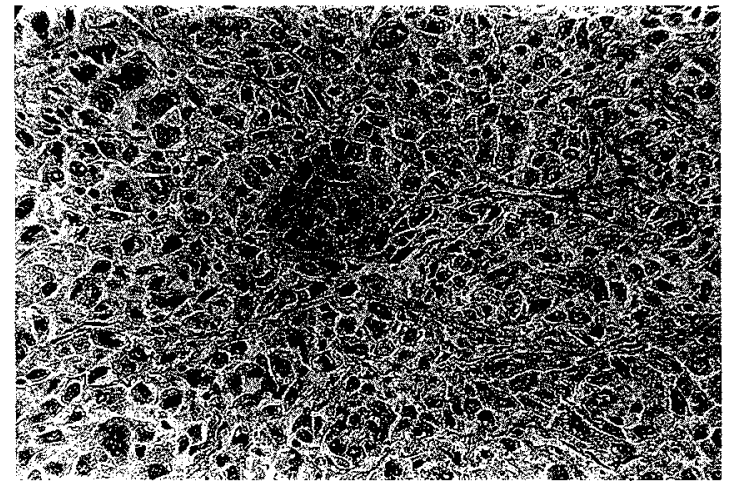

Fig. 10: The photomicrograph of a hepatoma immunohistologically stained for BGBP. No positively stained cells were present.

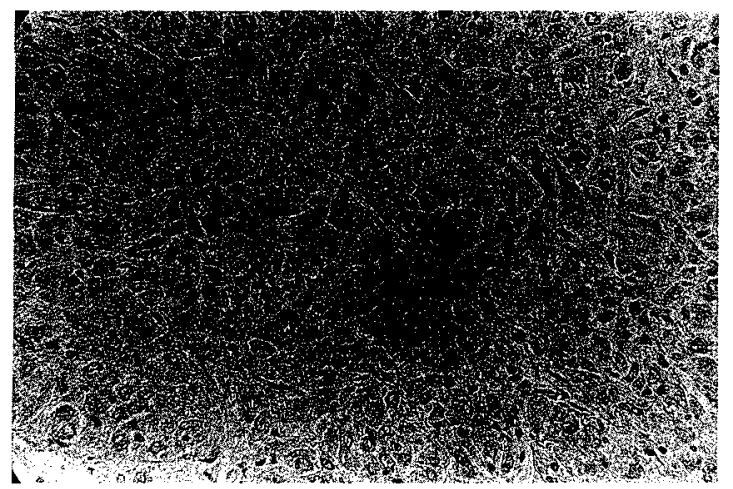

Fig. 11: The photomicrograph of a hepatoma stained with Orcein method for hepatitis B surface antigen. No positively stained cells were present. 
elution curve by HPLC as shown in the Fig. 2. The molecular weight of BGBP was 11,990 according to the estimation using liquidchromato-mass-spectrometry by the Department of instrumental analysis, Takara Shuzo $\mathrm{Co}^{26}$. The molecular sieving, on the other hand, does not seem to be a good method for the separation, because of the absence of clear-cut peak of BGBP when the other fractions like marker proteins are present besides BGBP. It might also indicate that BGBP have the ability to combine the other enzymes besides B-Gase in the other organisms like hepatitis B virus which fit to use metabolic machinery of liver cells. The speculation should be justified since BGBP is not a specific product by $M L^{17.27}$, and it seems to combine other proteins beside B-Gase as suggested by the elution curves on column chromatography as written in results. The temporal conclusion, might also suggest the possibility of the growth disturbance of some microorganisms including ML in vivo by the elimination of BGBP function by immunological or biochemical means.

Activity of BGBP: Untreated, and treated BGBP with $6 \mathrm{M}$ urea but not SDS seemed to retain the activity, indicating again the best way to purify the BGBP is preparatory electrophoresis using the buffer containing urea without treating the Fr. 2 with SDS. It seemed that the present experiment to test the activity of BGBP was somehow successful but the results of repeated experiments indicated that the successful result seemed to depend on the proper choice of nitrocellulose sheets in which we need to work to improve more reproducibility.

Immunohistologic staining for B-Gase and BGBP: Our present and previous studies revealed that the rabbit antiserum against the BGBP of HI-75 react not only with ML but also with the other microorganisms, grown intracellularly, hepatitis B infected liver cell cytoplasm $^{28}$ and legume extracts ${ }^{17}$ indicating vast distribution of BGBP among plants. This will assure us the equivalent immunogen to BGBP from HI-75, from the easier source to acquire. The knowledge on the nature of BGBP from HI-75 obtained by the present study will make the procedure easier. The immunoreactivity of BGBP in the tissue after hyaluronidase digestion of the tissue sections ${ }^{28}$ might suggest that BGBP attract not only the enzyme but HA likewise. The coating of antigens by HA might mask the antigenicities of microorganisms and help microorganisms to be protected from immunosurveilance system of the host.

\section{CONCLUSIONS}

1. The present study showed that the best method to purify the $\beta$-glucuronidase binding protein (BGBP) from the mycobacterium HI-75 was preparatory electrophoresis in the final step of its purification.

2. Immunohistological study suggested that $M$. leprae in leprosy patient obtain the activity of $\beta$-glucuronidase by fixing the host enzyme to this BGBP.

3. This BGBP was shown to be present not only in $M$. leprae but apparently in the other microorganisms such as $M$. avium-intracellulare and hepatitis $B$ virus.

Acknowledgments: The authors greatly appreciate the chairmen of US-Japan Cooperative Medical Science Program, Drs. Masahide Abe, Tatsuo Mori and Hajime Saitoh and the former and present directors of the research laboratories of Sankyo Pharmaceutical Company, especially Drs. Minoru Tanaka and Yukinori Kawahara, for their financial supports for the study. Our sincere gratitudes also go to Dr. Yukio Ogata, former professor of bacteriology and Dr. Akira Wakisaka, professor of biochemistry at Kyorin University School of Medicine for their technical suggestions and supports with their kind encouragements to use 
their facilities and apparatuses likewise MS. Tae Akioka and Mr. Yoshiharu Ogawa, Takara Shuzo Co. for the determination of the molecular weight of BGBP by liquid-chromatomass spectrometry.

\section{REFERENCES}

1. Matsuo E \& Skinsnes OK: Acid mucopolysaccharide metabolism in leprosy. 2. Subcellular localization of hyaluronic acid and $\beta$-glucuronidase in leprous infiltrates suggestive of host-mycobacterium leprae metabolic relationship. Int. J. Lepr. 42: 399-411, 1974.

2. Matsuo E, Sasaki N \& Skinsnes OK: On the pathologic significance of beta-glucuronidase in leprosy. Extraction using chloroform treatment, ethanol precipitation, trypsin digestion and gel filtration and suggested characteristics of the enzyme. US-Japan Medical Science Program. 1986 Annual reports, pp. 126-132, USJapan Medical Science Program, Leprosy section, Tokyo, 1987, (in Japanese).

3. Skinsnes OK, Matsuo E, Chang PHC \& Anderson B: In vitro cultivation of leprosy bacilli in hyaluronic acid based medium. 1. Preliminary report. Int. J. Lepr. 43: 193-203, 1975.

4. Stanford JL, Bird RG, Carswell JW, Draper P, Lowe C, McDougal AC, McIntyre G, Pattyn SR \& Rees RJW: A study of alleged leprosy bacillus strain HI-75. Int. J. Lepr. 45: 101-106, 1977.

5. Fujimiya T, Kawazu K \& Sasaki N: On the foot-pad inoculation study of a mycobacterium originally separated from a leproma. Japanese Journal of Leprosy. 55: 127, 1986 (in Japanese). 6. Tasaka H, Department of bacteriology, Hiroshima University School of Medicine: personal communication.

7. Williams DL, GWL Hansen's Disease Research Laboratory: personal communication.

8. Grange JM, ed.: Mycobacteria and human disease, Edward Arnold, Baltimore, 1988.

9. Koticha KK, ed.: Leprosy, A Concise Text, Darshan K. Koticha, Bombay, 1990.

10. Matsuo E, Sasaki N \& Skinsnes OK: On the immunohistologic staining of betaglucuronidase in paraffine-embedded tissue. The requirement of peanut oil to deparaffinize and cardiolipin and lecithin for staining. 21st Joint Conference on Leprosy Research, USJapan Cooperative Medical Science Program, pp. 119-126, Osaka, 1986.

11. Matsuo E, Sasaki N \& Skinsnes OK: On the combination of beta-glucuronidase and a mycobacterium HI-75, US-Japan Medical Science Program, 1987 Annual reports, pp. 141-146, US-Japan Medical Science Program, Leprosy section, Tokyo, 1988, (in Japanese).

12. Matsuo E, Sasaki N \& Skinsnes O K: In vitro binding of beta-glucuronidase to a mycobacterium HI-75. 23rd Joint Conference on Leprosy Research, US-Japan Cooperative Medical Science Program, pp. 40-44, Nara, 1988.

13. Matsuo E, Sasaki N \& Skinsnes OK: On the soluble fraction of mycobacterium scrofulaceum HI-75 originally separated from human leproma, which combine betaglucuronidase. 24th Joint Conference on Leprosy, The US-Japan Cooperative Medical Science Program. pp. 77-79, 1989.

14. Matsuo E, Sasaki N \& Skinsnes OK: Combination of beta-glucuronidase and soluble fraction derived from a mycobacterium HI-75 (Preliminary study), US-Japan Medical Science Program, 1988 Annual reports, pp. 149-154, US-Japan Medical Science Program, Leprosy section, Tokyo, 1989, (in Japanese).

15. Matsuo E, Komatsu A, Sasaki N \& Skinsnes OK: On the extraction of receptor for beta-glucuronidase from mycobacterium scrofulaceum (HI-75) and immunostaining of that in leproma. US-Japan Medical Science Program. 1989 Annual reports, pp. 143-148, US-Japan Medical Science Program, Leprosy 
section, Tokyo, 1990, (in Japanese).

16. Miyazaki $\mathrm{G}$, ed.: High performance liquid chromatography. Hirokawa Publishing Co., Tokyo, 1991 (in Japanese).

17. Matsuo E, Komatsu A, Maekawa S, Matsushita A, Sumiishi A, Sasaki N \& Skinsnes OK: On the common immunogenicity of pisum sativum derived fraction to the receptor for beta-glucuronidase (BGR), of a mycobacterium HI-75, US-Japan Cooperative Medical Science Program, pp. 218-222, 1993.

18. Hayashi M, Nakajima Y \& Fishman W H: The cytologic demonstration of $\beta$ glucuronidase employing naphthol AS-BI glucuronide and hexazonium pararosanilin; a preliminary report. J. Histochem. Cytochem. 12: 293.297, 1964.

19. Ishikawa E, Kawai $\mathrm{T} \&$ Miyai $\mathrm{K}$, ed: Enzyme immunoassay, 2nd Ed., Igaku Shon, Tokyo, 1982.

20. Avrameas S: Coupling of enzymes to proteins with glutaraldehyde. Use of the conjugate for detection of antigens and antibodies. Immunochemistry, 6: 43, 1969.

21. Herbert WJ: Passive haemagglutination with special reference to the tanned cell technique. In: Handbook of Experimental Immunology, third ed. by Weir DM, Vol. 1, 20.1-20. 20, Blackwell, Oxford, 1978.

22. Matsuo E, Komatsu A, Sasaki N \& Skinsnes OK: On the possible cross. immunoreactivity of the beta-glucuronidase receptor of scrofulaceum $\mathrm{HI}-75$ with that in globi in leproma. An immunohistologic study. 25th Joint Conference on Leprosy Research, The US-Japan Cooperative Medical Science Program, pp. 34-37, 1990.

23. Prophet EB, Mills B, Arrington JB \& Sobin LH, ed.: Laboratory Method in Histotechnology. pp. 208 Armed Forces Institute of Pathology, Washington, D.C., 1992.

24. Lillie RD \& Fuller HM, ed.: Histopathologic technique and practical histochemistry. p. 735, McGraw-Hill, New York, 1976.

25. Hsu SM, Raine L \& Fanger H: Use of avidin-biotin peroxidase complex (ABC) in immuno-peroxidase techniques: a comparison between $\mathrm{ABC}$ and unlabeled antibody (PAP) procedures. J. Histochem. Cytochem. 30: 1079 1082, 1982.

26. Akioka T \& Ogawa Y, Department of instrumental analysis, Takara Shuzo Co.: personal communication.

27. Matsuo E, Komatsu A, Takatsu A, Sumiishi A, Sasaki N \& Skinsnes OK: On the crossimmunoreactivity of the receptor for betaglucuronidase (BGR) of $M$. leprae with the extracts of beans, US-Japan Cooperative Medical Science Program, pp. 62-65, 1992.

28. Matsuo E, Komatsu A, Murakami M, Terada M, Sasaki N \& Skinsnes OK: On the pathologic significance of the receptor for betaglucuronidase (BGR) of mycobacterium leprae, especially in the relationship to its other antigen. 26th Joint Conference on Tuberculosis and Leprosy. US-Japan Cooperative Medical Science Program. pp. 194-198, 1991. 


\title{
Beta-Glucuronidaseに対する微生物由来の結合蛋白質について。
} その精製，抗体作成ならびに癩腫および他の感染症病巣における局在。

\section{松尾英一 ${ }^{1)}$, 小松明男 ${ }^{11}$, 前川傑1), 古野之洋 ${ }^{11}$, 松下晃子 ${ }^{11}$, 住石歩 ${ }^{1)}$, 佐々木紀典 ${ }^{2)}$, Olaf K. Skinsnes ${ }^{3)}$}

\author{
1）杏林大学医学部病理学教室，2）東北新生園，3） 中山医科大学病理学教窒 \\ キーワード：らい, $\beta$ ーグルクロニダーゼ, $\beta$ ーグルクロニダーゼ結合蛋白質。
}

らい菌は，末梢神経やらい細胞に多量に含まれ るヒアルロン酸を自己に結合させた宿主由来の酵 素を用いて分解し，その産物を代謝して増殖する と考えられる。よって本検索ではこの酵素結合蛋 白質 $(\beta-$ glucuronidase binding protein: BGBP) の精製方法，抗体作製並びに感染病巣における局 在について検討した。

BGBP精製の原料としては，らい腫から分離さ れた抗酸菌HI-75をヒアルロン酸の構成分子であ るグルクロン酸とN-アセチグルコサミンを加え た小川培地で培着して用いた。なお, BGBPの分布 はらい腫以外にB型肝炎やM. avium-
intracellulare(MAI)による感染病巣についても 免疫組織学的に検討した。

以上の結果, BGBPの精製については, 精製の最 終段階で調整用電気泳動を用いる事が最良の方法 であり，分子篩クロマトグラフィーは恐らく BGBPが共存する分子と結合する性質を有するた め, 適さない事が分かった。また, BGBPはらい腫 ならびにB型肝炎ウイルスやMAIの感染病巣に も存在する事が分かった。以上はこれらの寄生 体もまたらら菌と類似した方法によって宿主の 代謝系を利用する能力を有する事を示唆すると考 えられた。 